Supporting Information for

\title{
From ordinary to extraordinary: insights into the formation mechanism and pH-dependent assembly/disassembly of nanojars
}

\author{
Basil M. Ahmed and Gellert Mezei* \\ Department of Chemistry, Western Michigan University, Kalamazoo, Michigan, USA \\ *Correspondent author. Email: gellert.mezei@wmich.edu
}

CONTENTS

PAGE

1. $\mathrm{pH}$ and absorbance measurement data (Table S1) S2

2. Mass spectrometric data (Figures S1-S14) S3

3. X-ray crystallographic data (Figure 15) $\quad \mathrm{S} 10$

4. ${ }^{1} \mathrm{H}$ NMR spectroscopic data (Figures S16-S20) $\quad$ S10

5. Thermogravimetric data (Figures S21, S22) S13 
Table S1. $\mathrm{pH}$ and visible absorbance measurements during the titration of $\mathrm{Cu}\left(\mathrm{NO}_{3}\right)_{2} /$ pyrazole $(3: 3$ molar ratio) with $\mathrm{NaOH}$.

\begin{tabular}{|l|l|l|l|l|l|}
\hline No. & $\begin{array}{c}\text { Equivalents } \\
\text { of } \mathrm{NaOH}\end{array}$ & $\begin{array}{c}\text { Volume of } \\
\text { NaOH }(\mathrm{mL})\end{array}$ & $\mathrm{pH}$ & $\begin{array}{c}\text { Temp. } \\
\left({ }^{\circ} \mathrm{C}\right)\end{array}$ & $\begin{array}{l}\text { Absorbance } \\
(\text { at } 668 \mathrm{~nm})\end{array}$ \\
\hline 1 & 0 & 0 & 3.88 & 28.0 & 0.171 \\
\hline 2 & 0.600 & 0.735 & 4.29 & 28.8 & 0.268 \\
\hline 3 & 1.200 & 1.470 & 4.43 & 28.1 & 0.355 \\
\hline 4 & 1.800 & 2.205 & 4.62 & 28.4 & 0.461 \\
\hline 5 & 2.400 & 2.940 & 4.80 & 28.5 & 0.558 \\
\hline 6 & 3.000 & 3.675 & 5.05 & 28.8 & 0.658 \\
\hline 7 & 3.600 & 4.410 & 5.54 & 28.1 & 0.750 \\
\hline 8 & 3.750 & 4.539 & 5.77 & 28.6 & 0.779 \\
\hline 9 & 3.840 & 4.704 & 5.93 & 28.9 & 0.782 \\
\hline 10 & 3.900 & 4.777 & 6.08 & 28.4 & 0.779 \\
\hline 11 & 4.000 & 4.900 & 6.23 & 28.9 & 0.776 \\
\hline 12 & 4.200 & 5.145 & 6.26 & 28.4 & 0.721 \\
\hline 13 & 4.500 & 5.512 & 6.31 & 29.5 & 0.610 \\
\hline 14 & 4.800 & 5.880 & 6.33 & 29.4 & 0.453 \\
\hline 15 & 5.100 & 6.247 & 6.50 & 30.0 & 0.366 \\
\hline 16 & 5.400 & 6.615 & 6.52 & 29.2 & 0.213 \\
\hline 17 & 5.550 & 6.798 & 6.62 & 29.0 & 0.152 \\
\hline 18 & 5.700 & 6.982 & 6.74 & 29.3 & 0.107 \\
\hline 19 & 5.850 & 7.166 & 6.92 & 28.9 & 0.045 \\
\hline 20 & 5.898 & 7.227 & 7.05 & 29.3 & 0.024 \\
\hline 21 & 5.949 & 7.288 & 7.19 & 29.5 & 0.010 \\
\hline 22 & 6.000 & 7.350 & 7.47 & 29.5 & 0.000 \\
\hline 23 & 6.150 & 7.533 & 9.46 & 29.5 & 0.013 \\
\hline 24 & 6.300 & 7.717 & 10.20 & 29.4 & 0.000 \\
\hline 25 & 6.600 & 8.085 & 10.90 & 29.0 & 0.004 \\
\hline 26 & 7.200 & 8.820 & 11.35 & 29.3 & 0.000 \\
\hline 27 & 7.800 & 9.555 & 11.57 & 29.3 & 0.000 \\
\hline 28 & 8.400 & 10.290 & 11.70 & 29.3 & 0.011 \\
\hline 29 & 9.000 & 11.025 & 11.82 & 29.5 & 0.000 \\
\hline
\end{tabular}




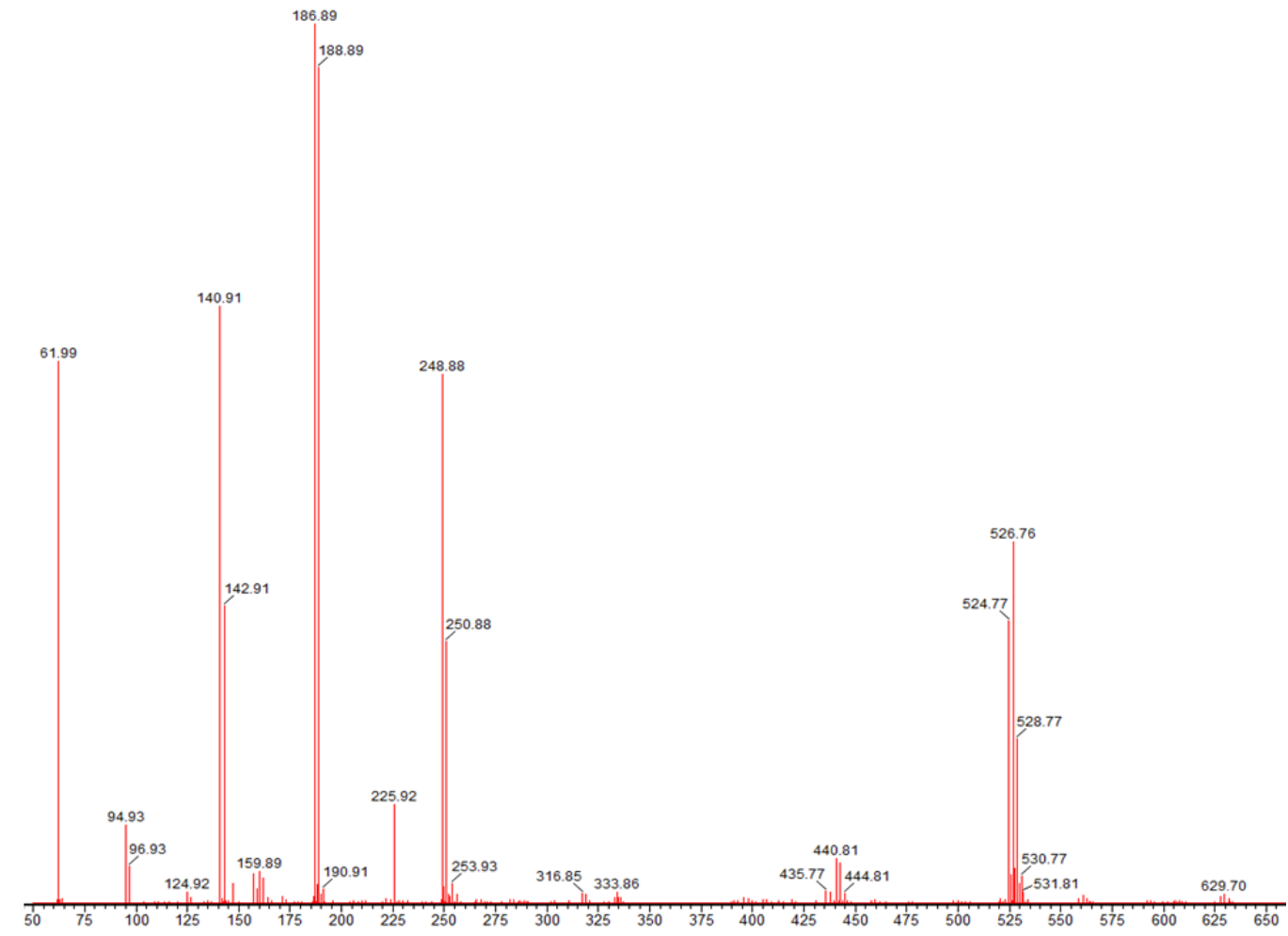

Figure S1. ESI-MS(-) spectrum (in $\mathrm{CH}_{3} \mathrm{CN}$ ) of the $\mathrm{Cu}\left(\mathrm{NO}_{3}\right)_{2} /$ pyrazole mixture (1:1) in tetrahydrofuran before the addition of $\mathrm{NaOH} / \mathrm{Na}_{2} \mathrm{CO}_{3}$ (time zero).

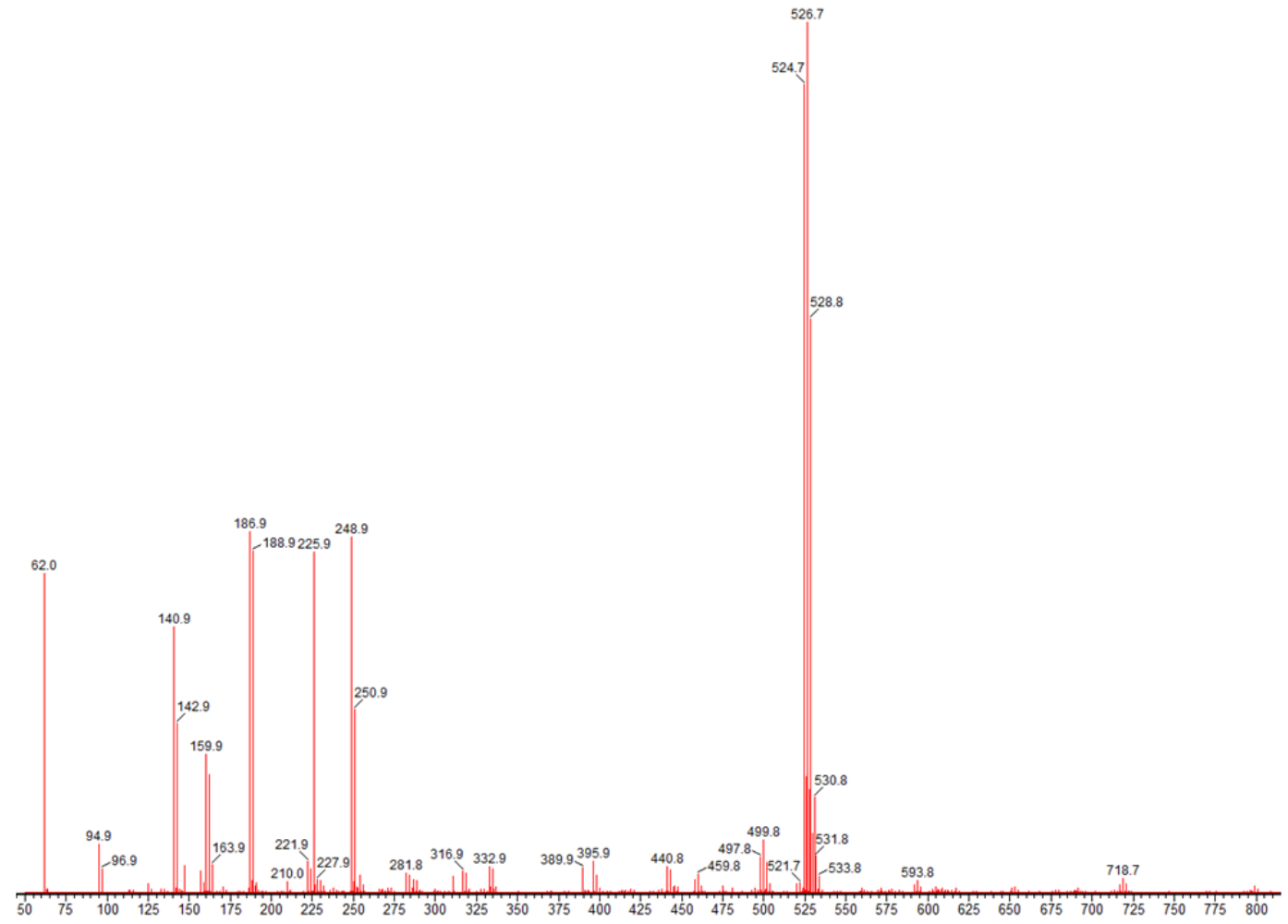

Figure S2. ESI-MS(-) spectrum (in $\mathrm{CH}_{3} \mathrm{CN}$ ) of the $\mathrm{Cu}\left(\mathrm{NO}_{3}\right)_{2}$ /pyrazole mixture (1:1) after 5 minutes of stirring with $\mathrm{NaOH} / \mathrm{Na}_{2} \mathrm{CO}_{3}$ in tetrahydrofuran. 


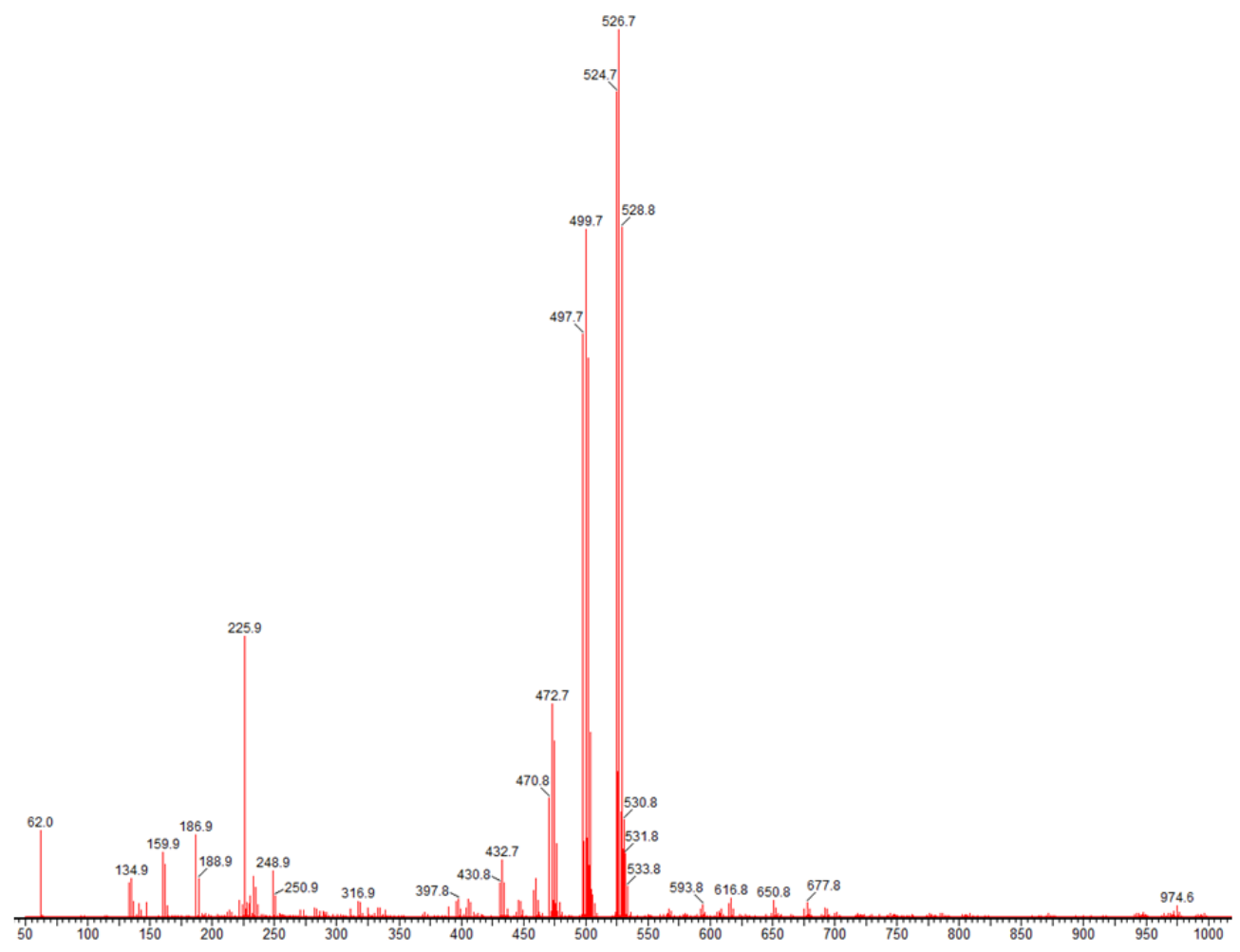

Figure S3. ESI-MS(-) spectrum (in $\mathrm{CH}_{3} \mathrm{CN}$ ) of the $\mathrm{Cu}\left(\mathrm{NO}_{3}\right)_{2}$ /pyrazole mixture (1:1) after 25 minutes of stirring with $\mathrm{NaOH} / \mathrm{Na}_{2} \mathrm{CO}_{3}$ in tetrahydrofuran.

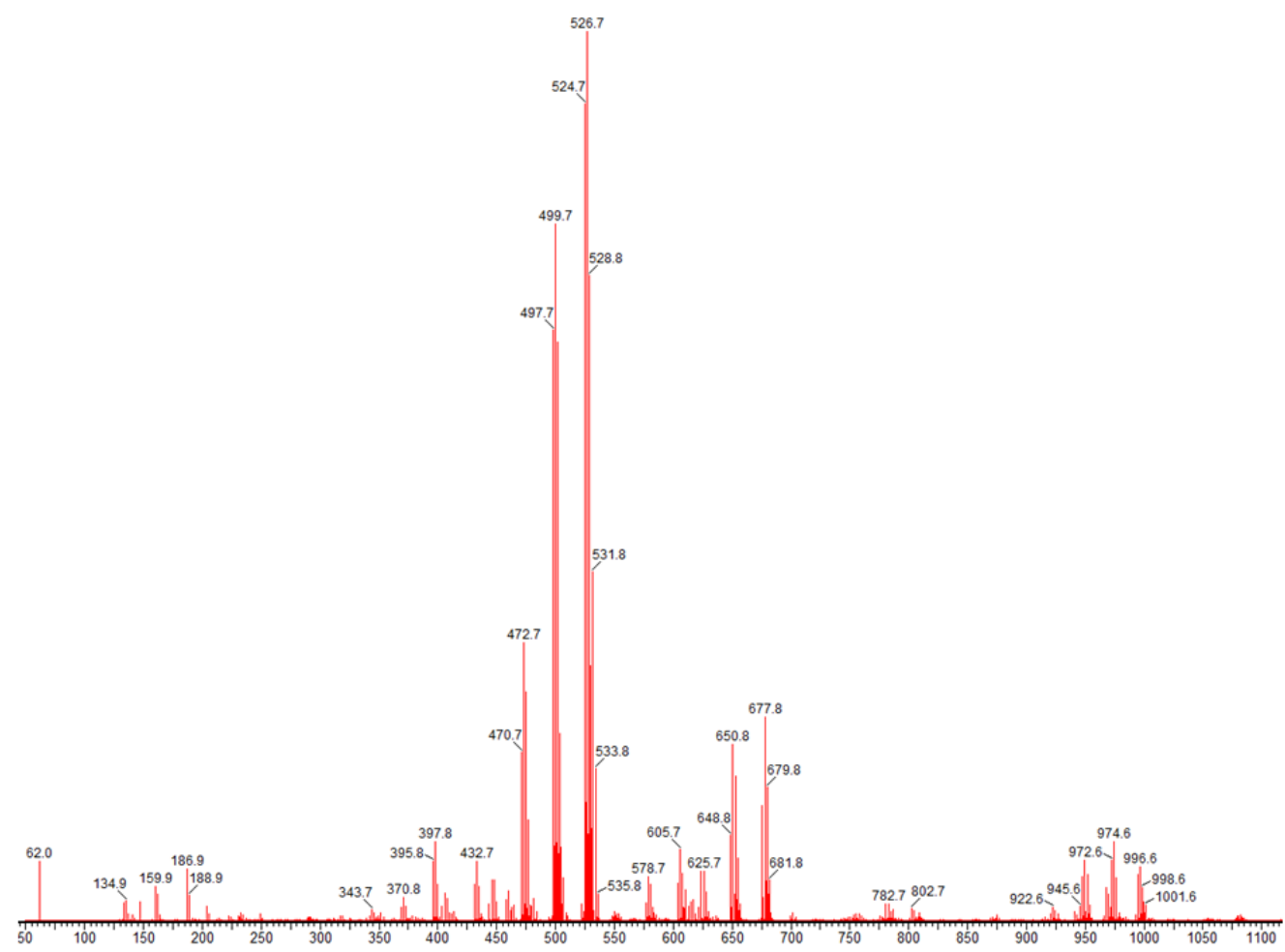

Figure S4. ESI-MS(-) spectrum (in $\mathrm{CH}_{3} \mathrm{CN}$ ) of the $\mathrm{Cu}\left(\mathrm{NO}_{3}\right)_{2}$ /pyrazole mixture (1:1) after 45 minutes of stirring with $\mathrm{NaOH} / \mathrm{Na}_{2} \mathrm{CO}_{3}$ in tetrahydrofuran. 


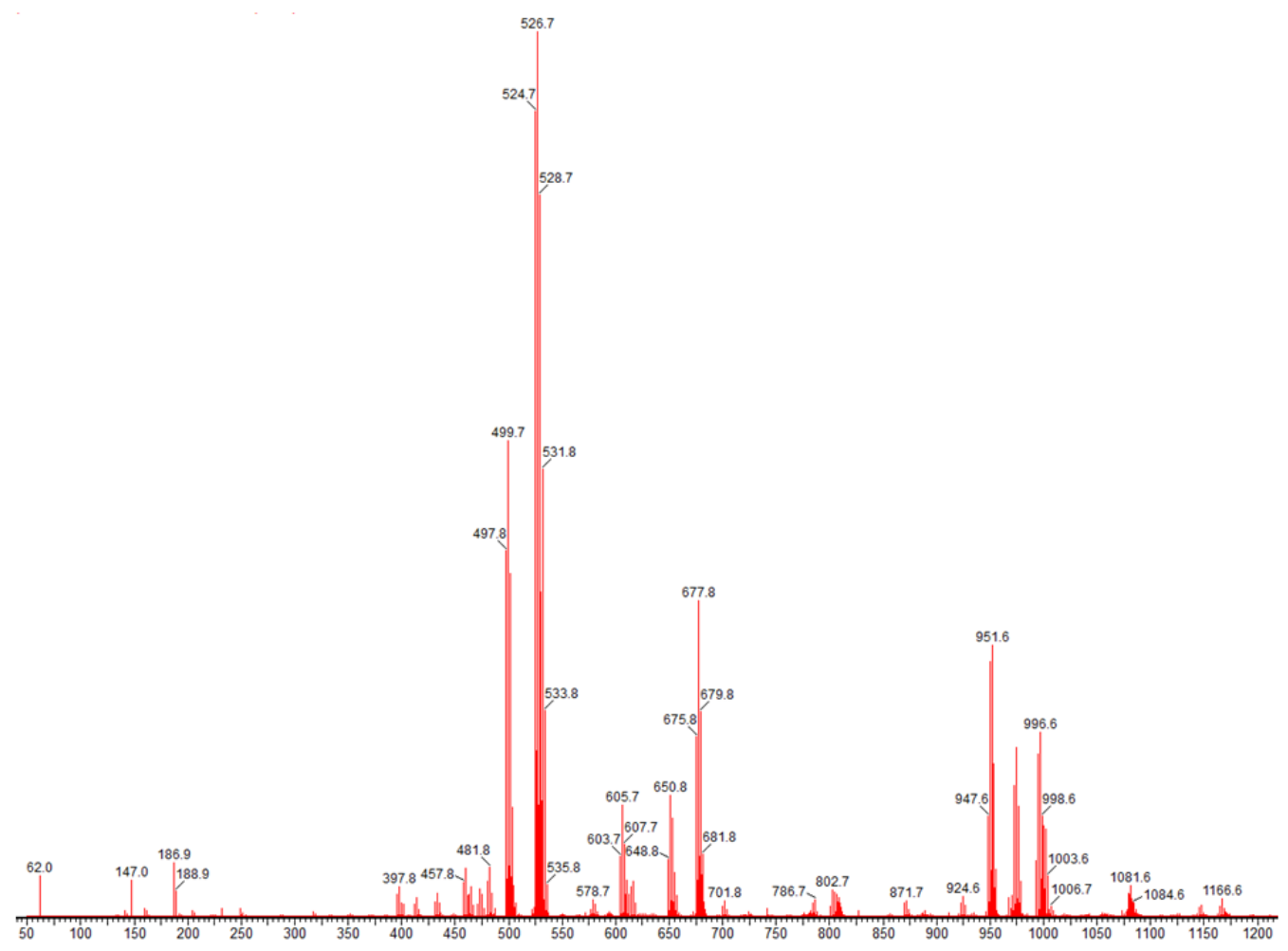

Figure S5. ESI-MS(-) spectrum (in $\mathrm{CH}_{3} \mathrm{CN}$ ) of the $\mathrm{Cu}\left(\mathrm{NO}_{3}\right)_{2}$ /pyrazole mixture (1:1) after 65 minutes of stirring with $\mathrm{NaOH} / \mathrm{Na}_{2} \mathrm{CO}_{3}$ in tetrahydrofuran.

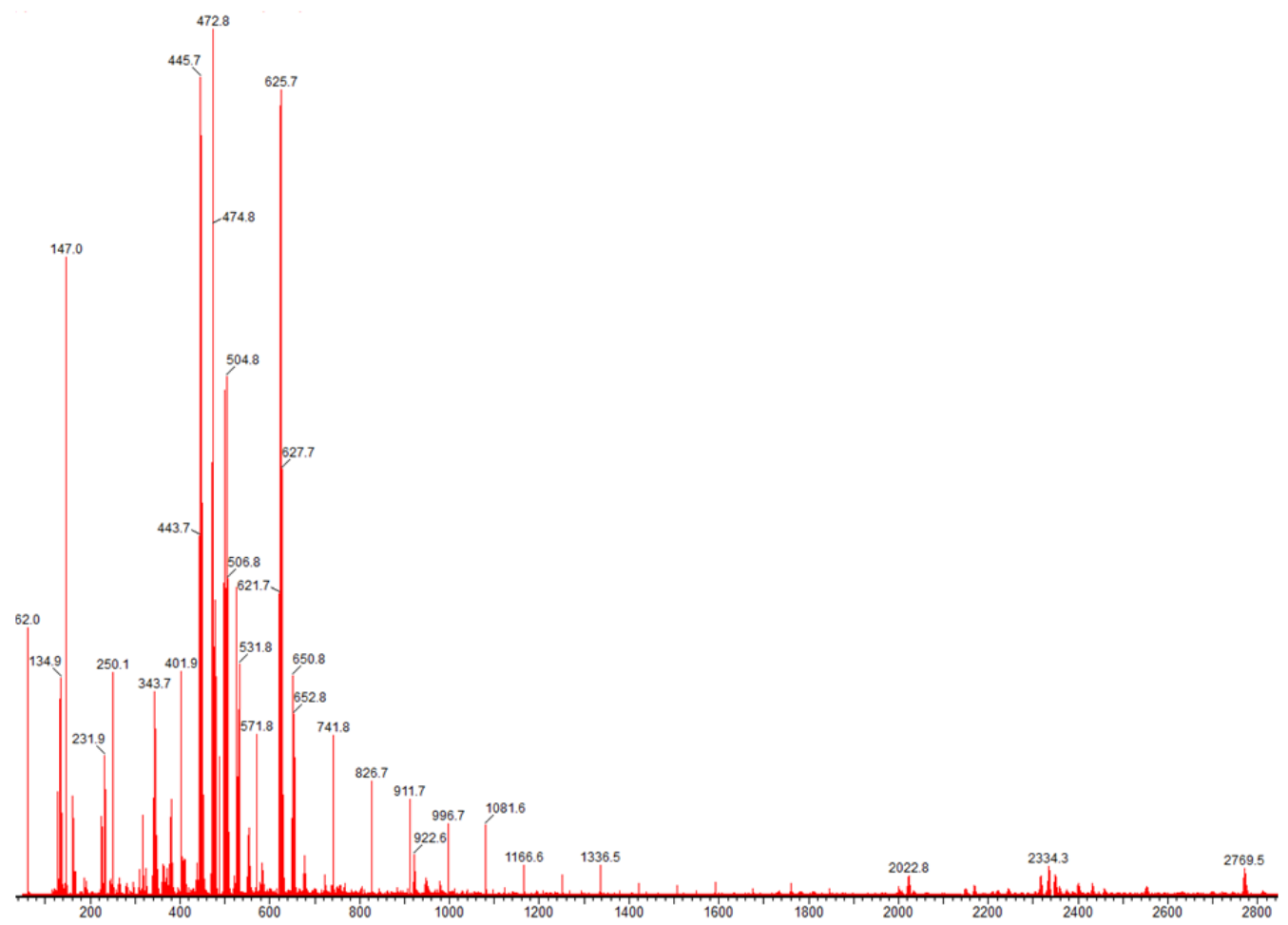

Figure S6. ESI-MS(-) spectrum (in $\mathrm{CH}_{3} \mathrm{CN}$ ) of the $\mathrm{Cu}\left(\mathrm{NO}_{3}\right)_{2} /$ pyrazole mixture (1:1) after 85 minutes of stirring with $\mathrm{NaOH} / \mathrm{Na}_{2} \mathrm{CO}_{3}$ in tetrahydrofuran. 


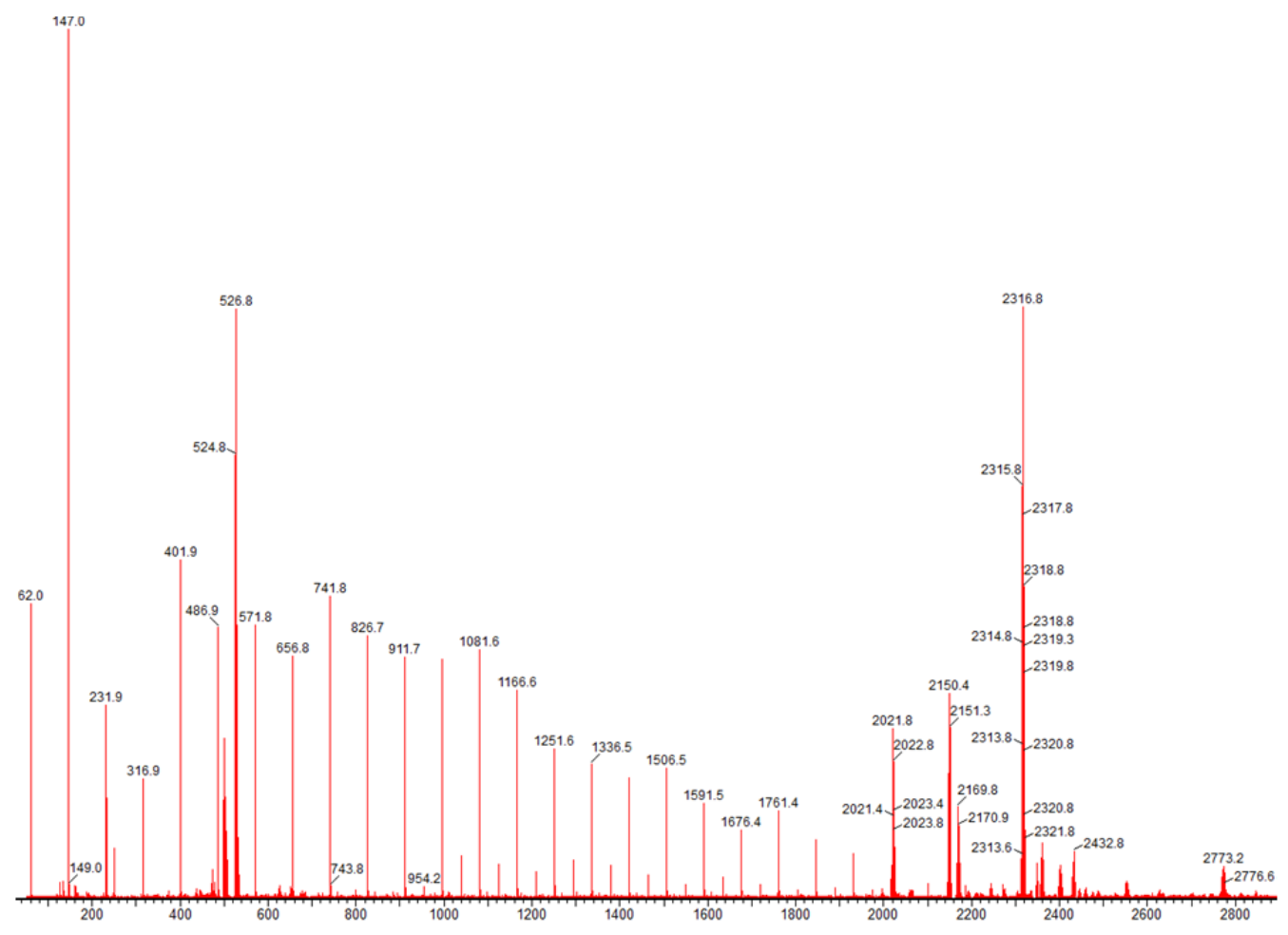

Figure S7. ESI-MS(-) spectrum (in $\mathrm{CH}_{3} \mathrm{CN}$ ) of the $\mathrm{Cu}\left(\mathrm{NO}_{3}\right)_{2}$ /pyrazole mixture (1:1) after 105 minutes of stirring with $\mathrm{NaOH} / \mathrm{Na}_{2} \mathrm{CO}_{3}$ in tetrahydrofuran.

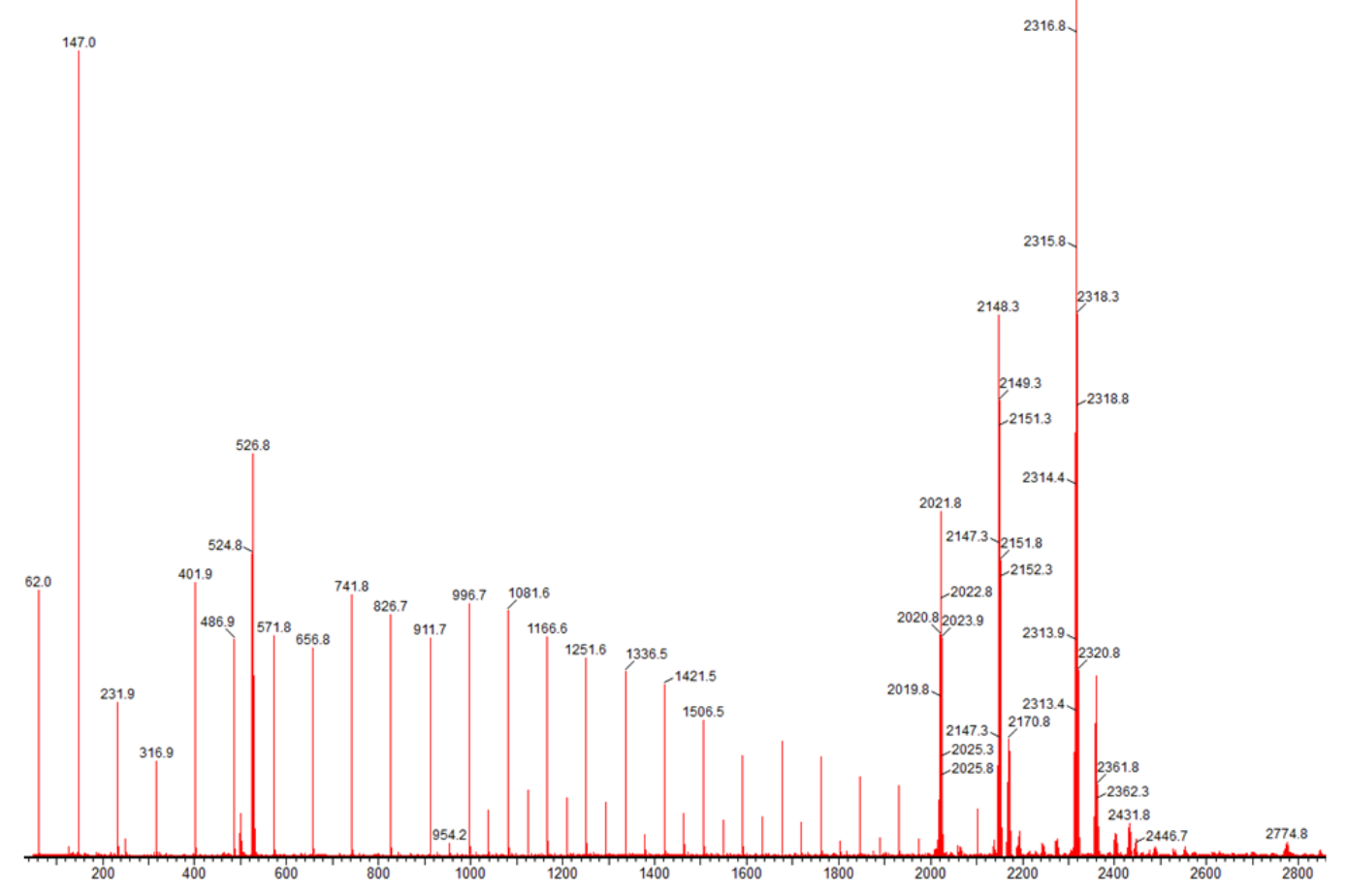

Figure S8. ESI-MS(-) spectrum (in $\mathrm{CH}_{3} \mathrm{CN}$ ) of the $\mathrm{Cu}\left(\mathrm{NO}_{3}\right)_{2}$ /pyrazole mixture (1:1) after 125 minutes of stirring with $\mathrm{NaOH} / \mathrm{Na}_{2} \mathrm{CO}_{3}$ in tetrahydrofuran. 


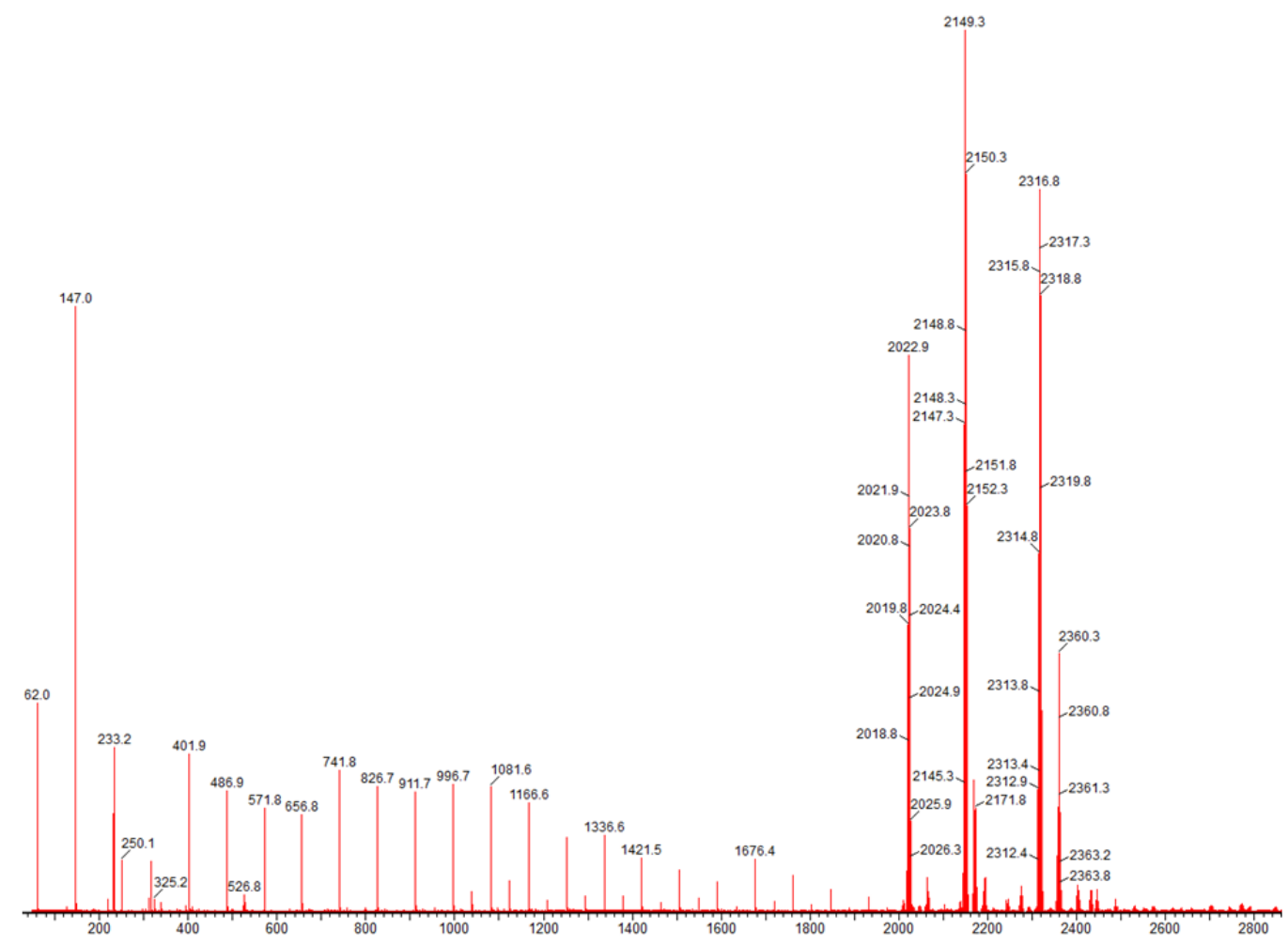

Figure S9. ESI-MS(-) spectrum (in $\mathrm{CH}_{3} \mathrm{CN}$ ) of the $\mathrm{Cu}\left(\mathrm{NO}_{3}\right)_{2} /$ pyrazole mixture (1:1) after 145 minutes of stirring with $\mathrm{NaOH} / \mathrm{Na}_{2} \mathrm{CO}_{3}$ in tetrahydrofuran.

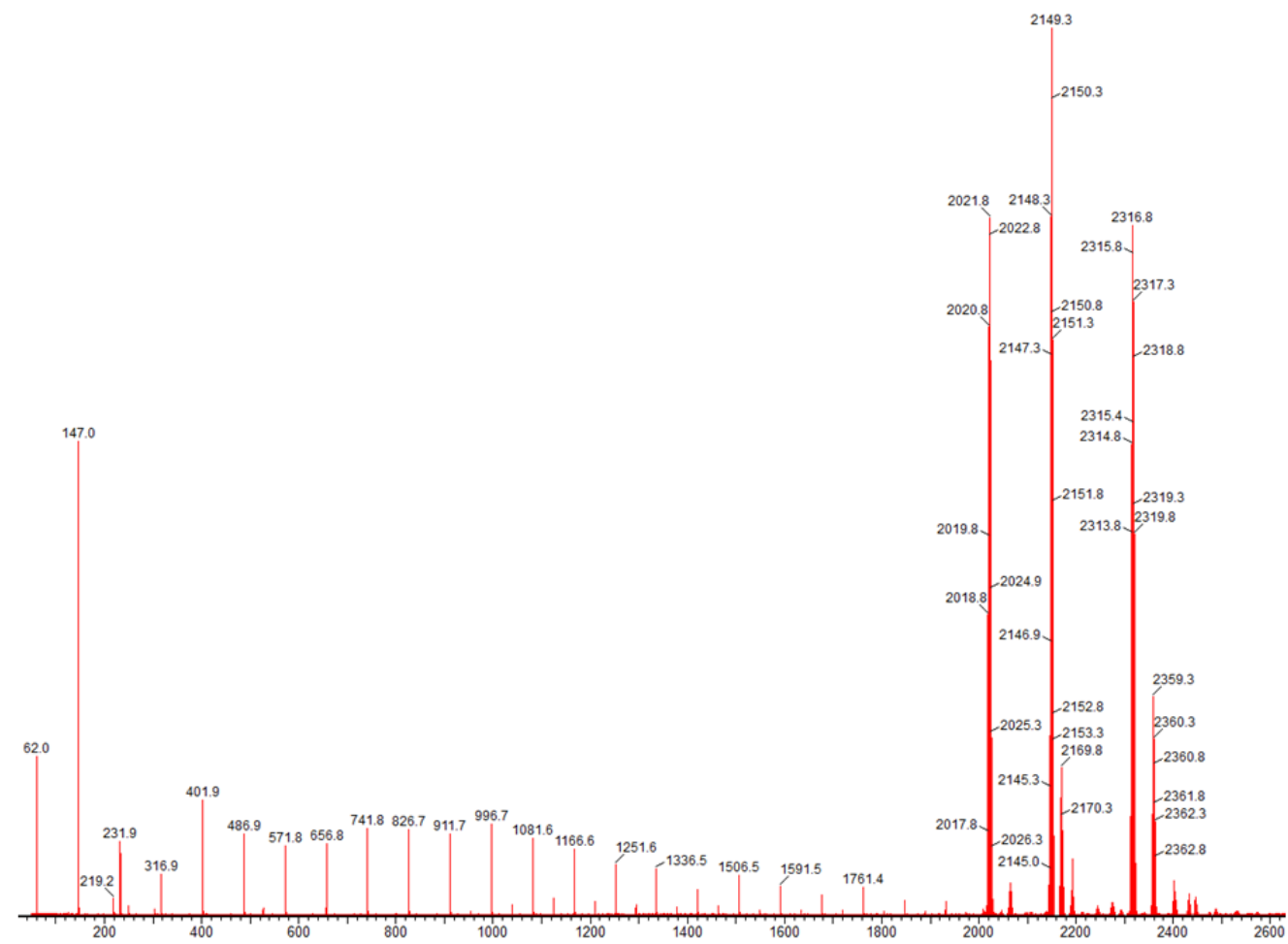

Figure S10. ESI-MS(-) spectrum (in $\mathrm{CH}_{3} \mathrm{CN}$ ) of the $\mathrm{Cu}\left(\mathrm{NO}_{3}\right)_{2} /$ pyrazole mixture (1:1) after 165 minutes of stirring with $\mathrm{NaOH} / \mathrm{Na}_{2} \mathrm{CO}_{3}$ in tetrahydrofuran. 


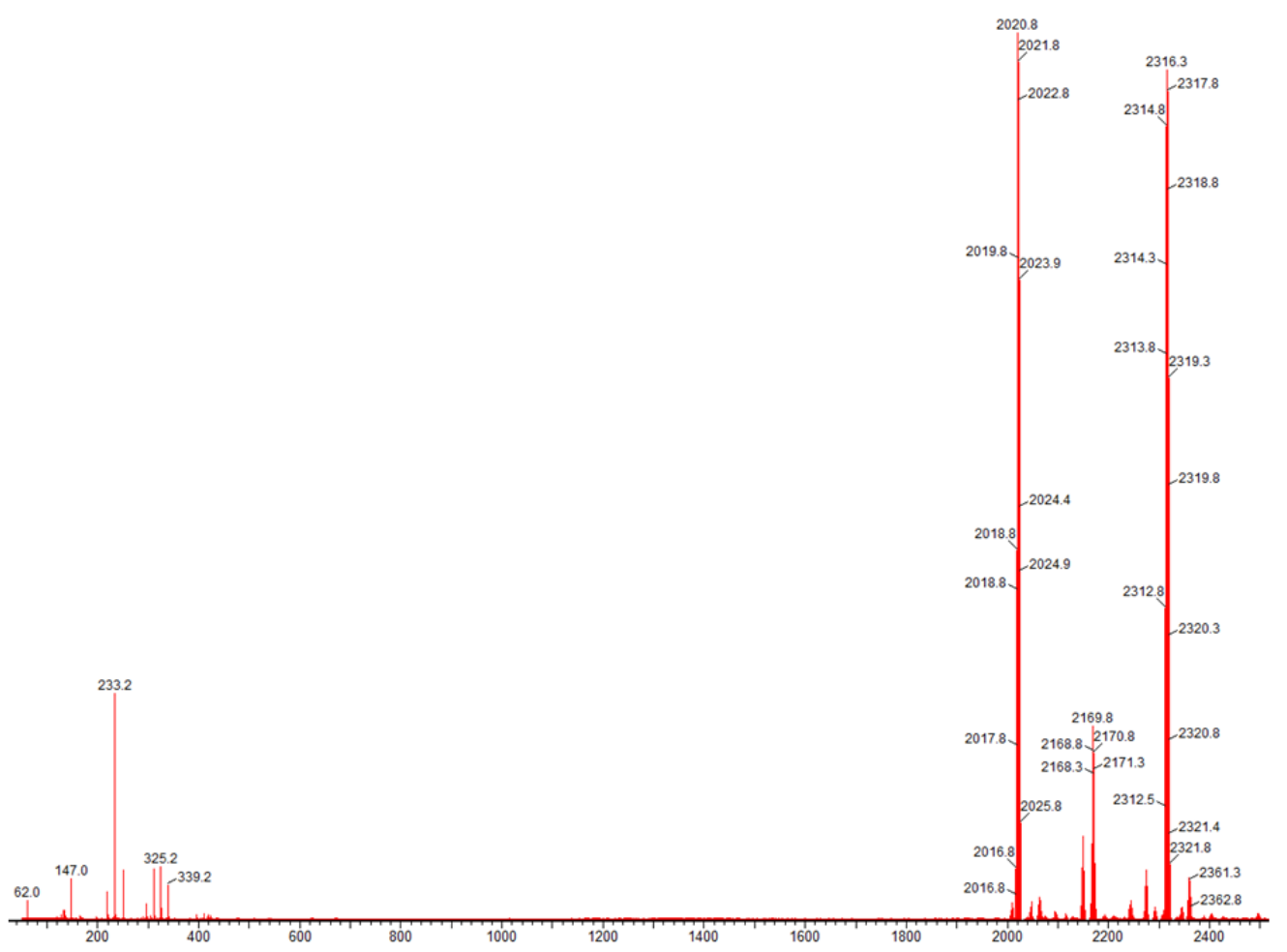

Figure S11. ESI-MS(-) spectrum (in $\mathrm{CH}_{3} \mathrm{CN}$ ) of the $\mathrm{Cu}\left(\mathrm{NO}_{3}\right)_{2} /$ pyrazole mixture (1:1) after 185 minutes of stirring with $\mathrm{NaOH} / \mathrm{Na}_{2} \mathrm{CO}_{3}$ in tetrahydrofuran.

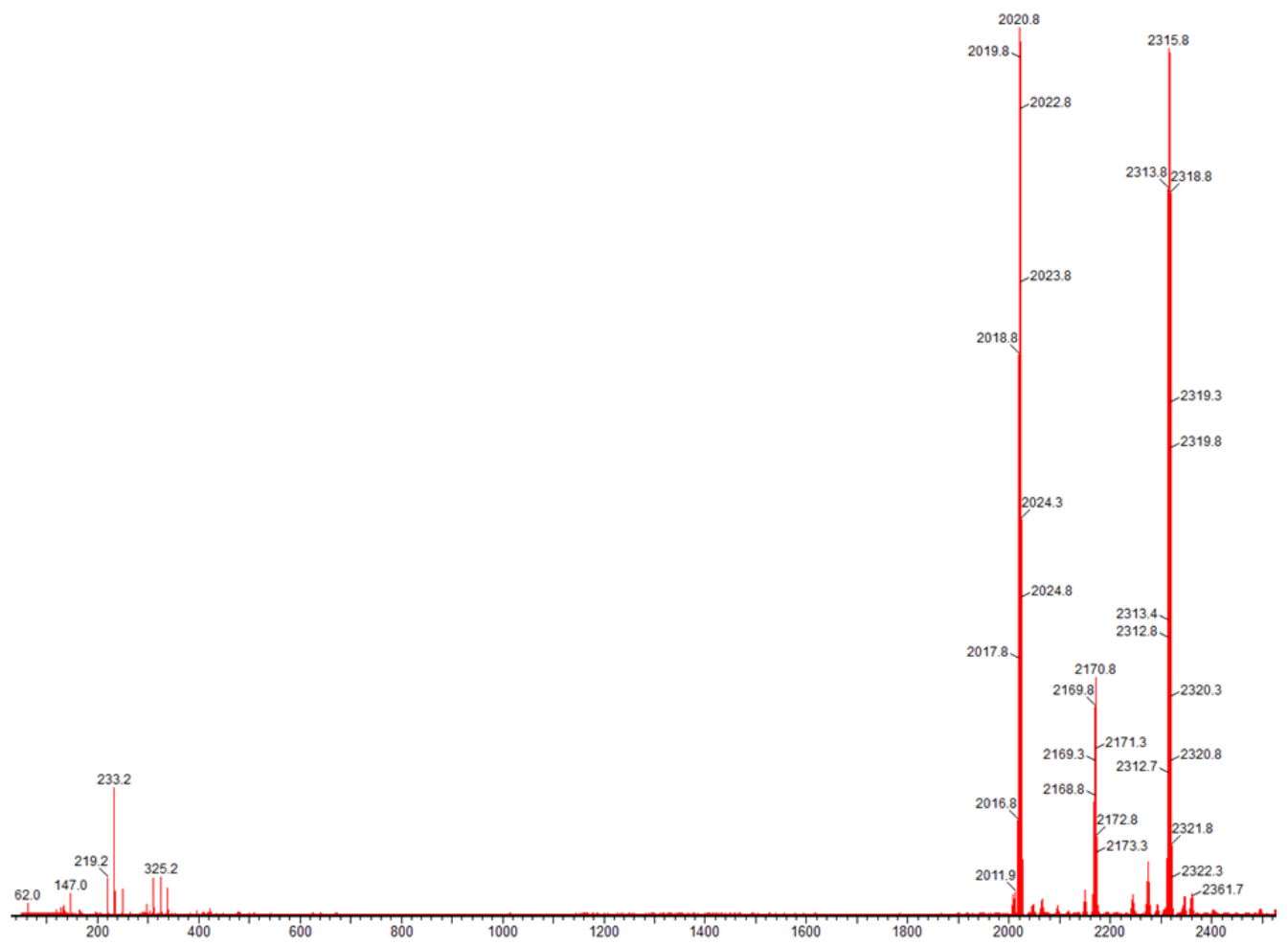

Figure S12. ESI-MS(-) spectrum (in $\left.\mathrm{CH}_{3} \mathrm{CN}\right)$ of the $\mathrm{Cu}\left(\mathrm{NO}_{3}\right)_{2}$ /pyrazole mixture (1:1) after 205 minutes of stirring with $\mathrm{NaOH} / \mathrm{Na}_{2} \mathrm{CO}_{3}$ in tetrahydrofuran. 


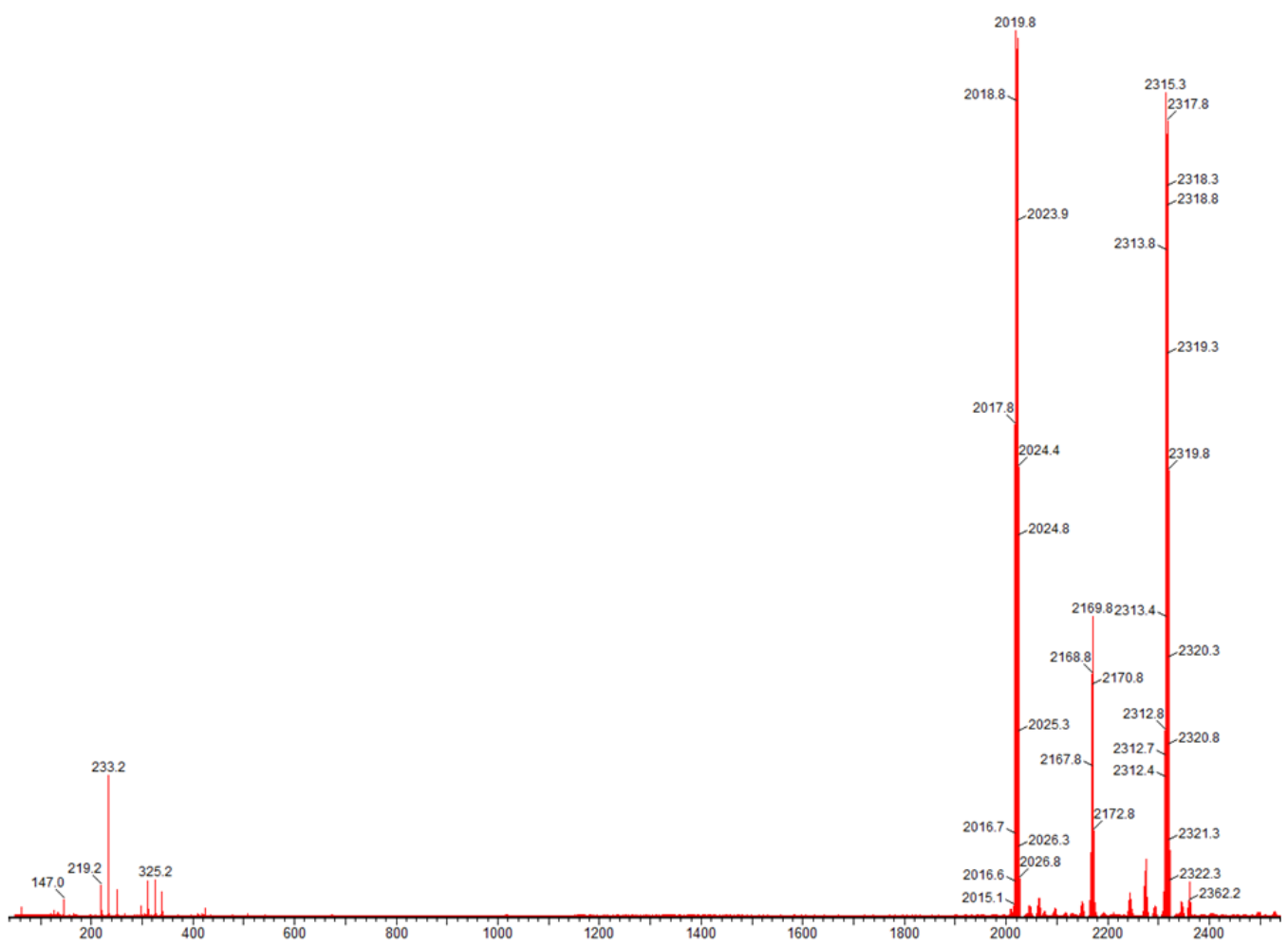

Figure S13. ESI-MS(-) spectrum (in $\mathrm{CH}_{3} \mathrm{CN}$ ) of the $\mathrm{Cu}\left(\mathrm{NO}_{3}\right)_{2} /$ pyrazole mixture (1:1) after 225 minutes of stirring with $\mathrm{NaOH} / \mathrm{Na}_{2} \mathrm{CO}_{3}$ in tetrahydrofuran.

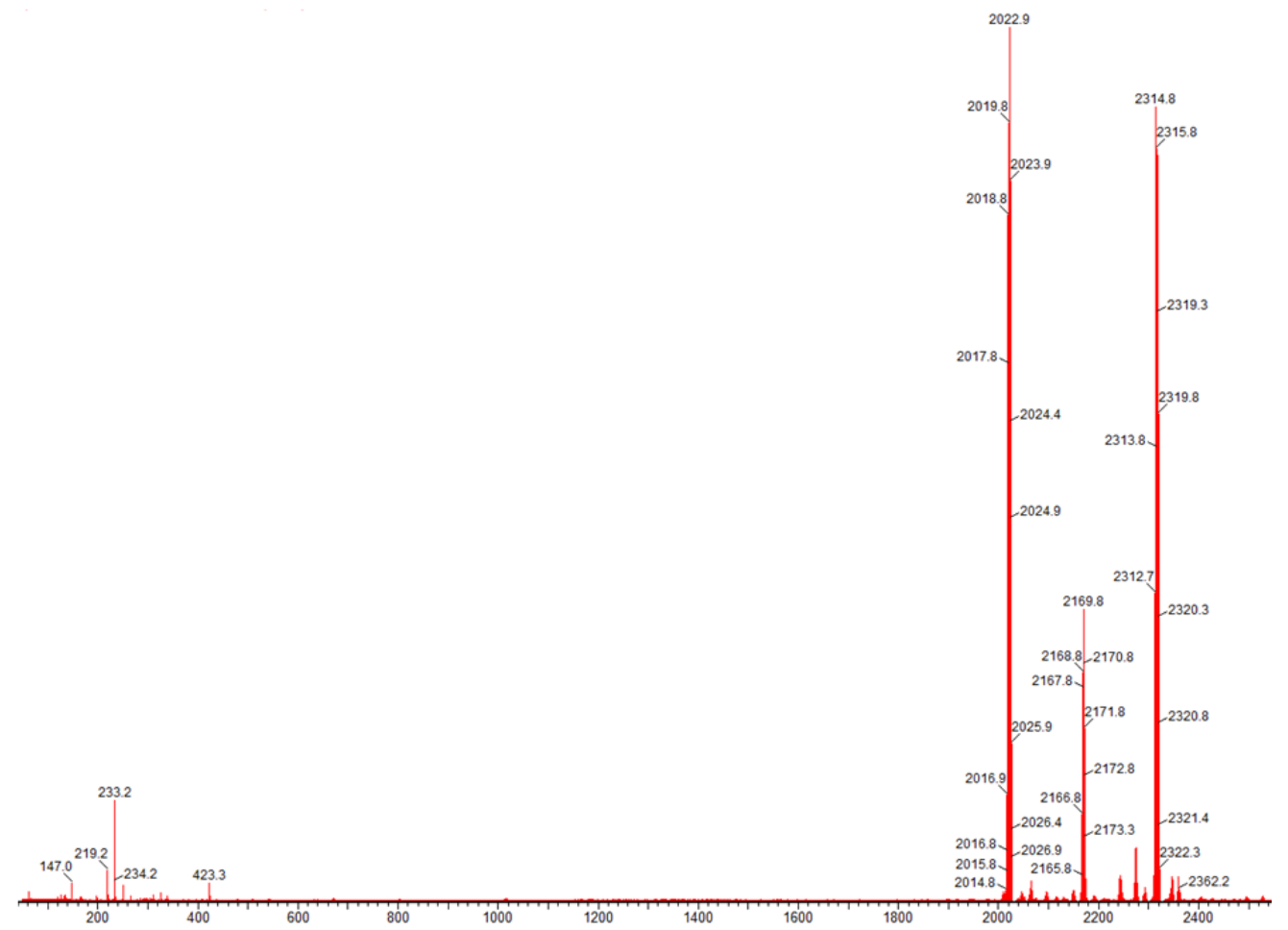

Figure S14. ESI-MS(-) spectrum (in $\mathrm{CH}_{3} \mathrm{CN}$ ) of the $\mathrm{Cu}\left(\mathrm{NO}_{3}\right)_{2}$ /pyrazole mixture (1:1) after 245 minutes of stirring with $\mathrm{NaOH} / \mathrm{Na}_{2} \mathrm{CO}_{3}$ in tetrahydrofuran. 


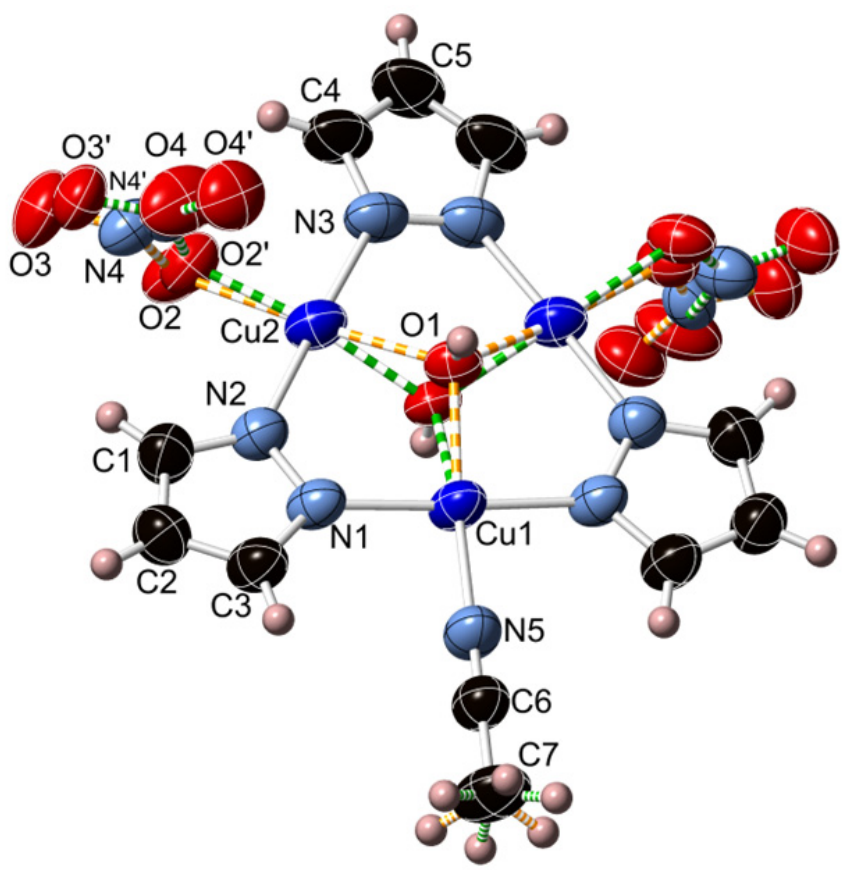

Figure S15. Thermal ellipsoid plot (50\% probability) of $\mathrm{Cu}_{3}\left(\mu_{3}-\mathrm{OH}\right)(\mu-\mathrm{pz})_{3}\left(\mathrm{NO}_{3}\right)_{2}\left(\mathrm{CH}_{3} \mathrm{CN}\right)(\mathbf{1} \mathbf{b})$.

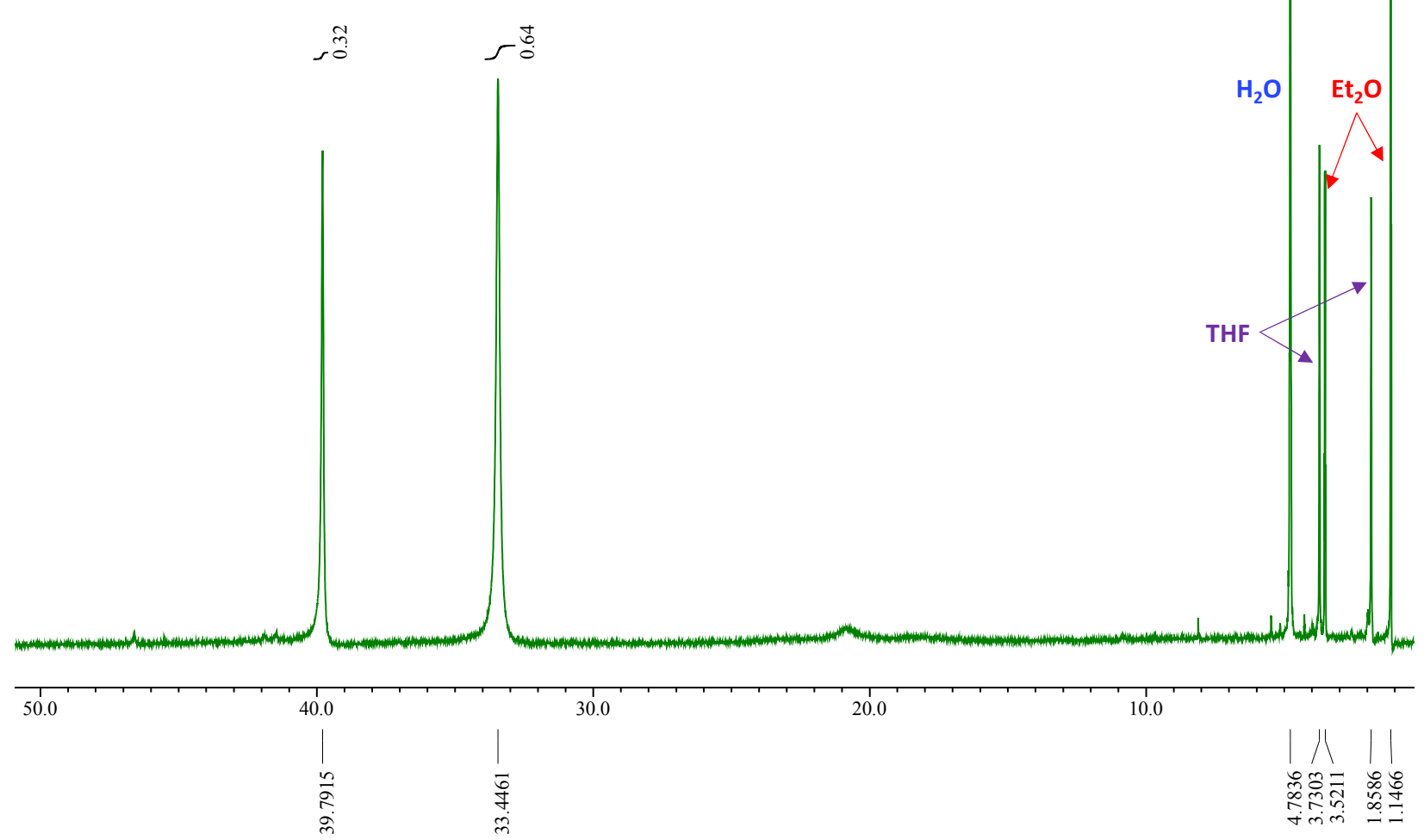

Figure S16. ${ }^{1} \mathrm{H}$ NMR spectrum $\left(400 \mathrm{MHz}, \mathrm{D}_{2} \mathrm{O}, 25^{\circ} \mathrm{C}\right)$ of $\mathrm{Cu}_{3}\left(\mu_{3}-\mathrm{OH}\right)(\mu-\mathrm{pz})_{3}\left(\mathrm{NO}_{3}\right)_{2}\left(\mathrm{H}_{2} \mathrm{O}\right)(\mathbf{1 a})$. 


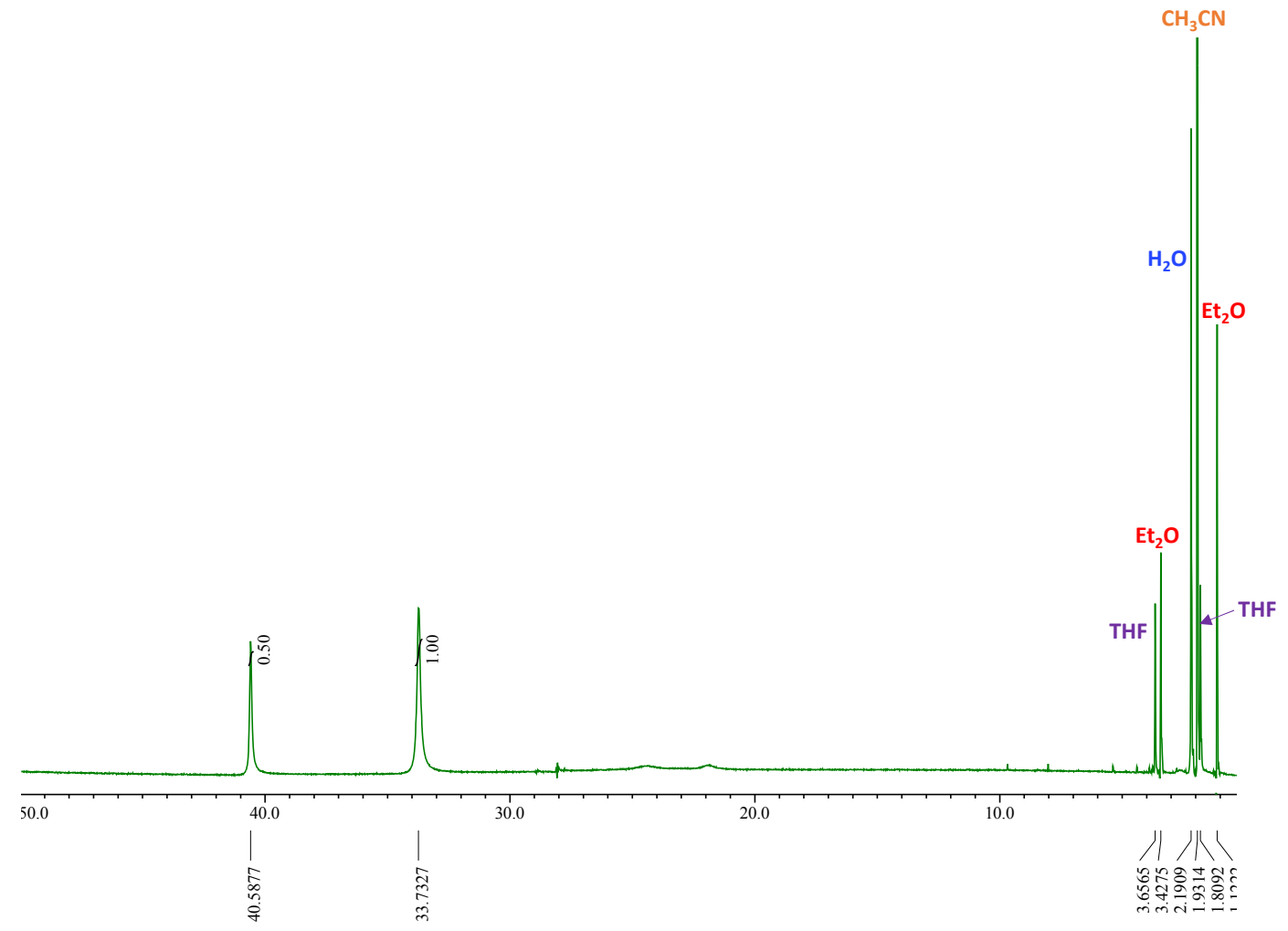

Figure S17. ${ }^{1} \mathrm{H}$ NMR spectrum $\left(400 \mathrm{MHz}, \mathrm{CD}_{3} \mathrm{CN}, 25^{\circ} \mathrm{C}\right)$ of $\mathrm{Cu}_{3}\left(\mu_{3}-\mathrm{OH}\right)(\mu-\mathrm{pz})_{3}\left(\mathrm{NO}_{3}\right)_{2}\left(\mathrm{H}_{2} \mathrm{O}\right)(\mathbf{1 a})$.

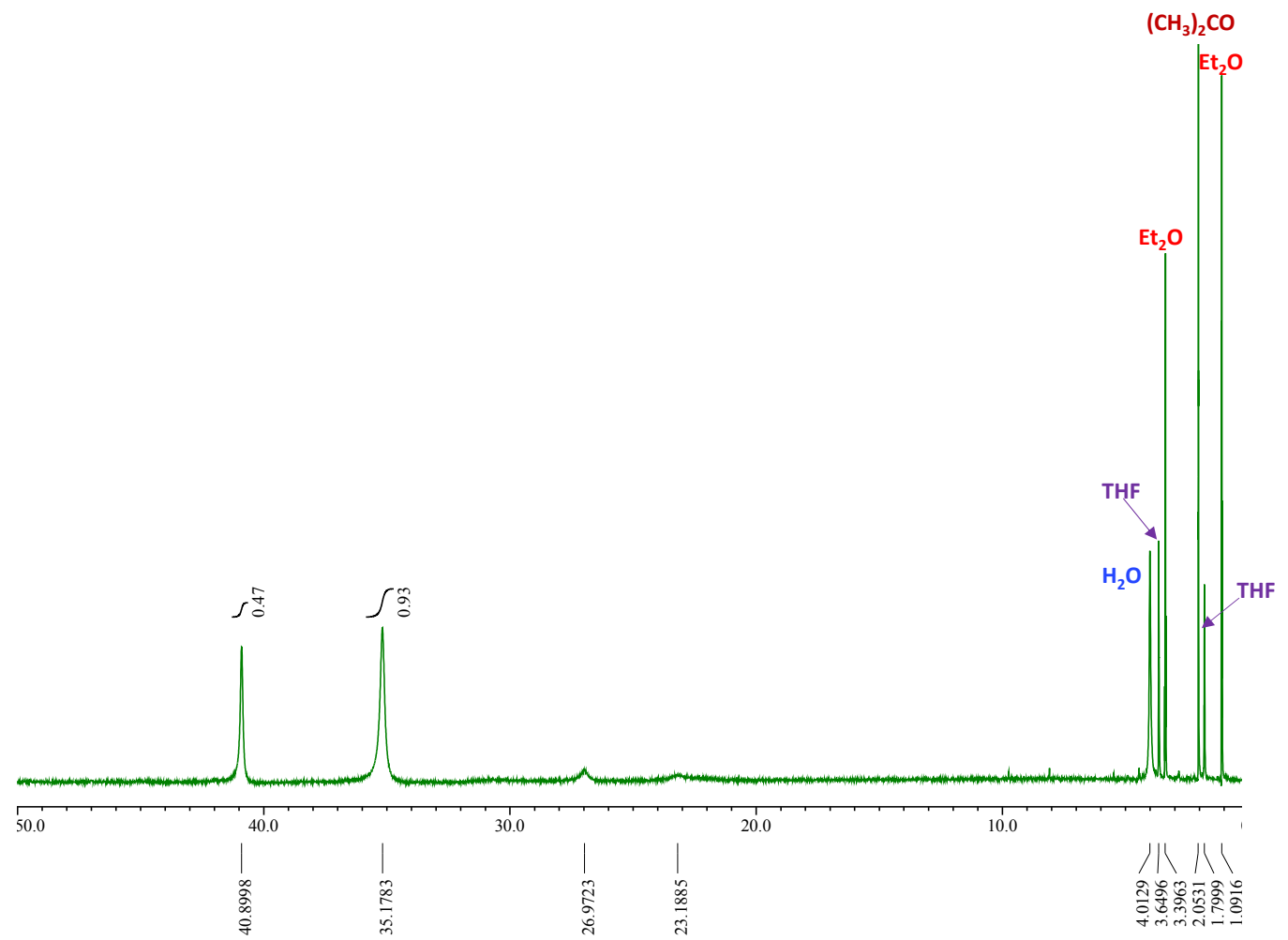

Figure S18. ${ }^{1} \mathrm{H}$ NMR spectrum $\left(400 \mathrm{MHz},\left(\mathrm{CD}_{3}\right)_{2} \mathrm{CO}, 25^{\circ} \mathrm{C}\right)$ of $\mathrm{Cu}_{3}\left(\mu_{3}-\mathrm{OH}\right)(\mu-\mathrm{pz})_{3}\left(\mathrm{NO}_{3}\right)_{2}\left(\mathrm{H}_{2} \mathrm{O}\right)(\mathbf{1 a})$. 


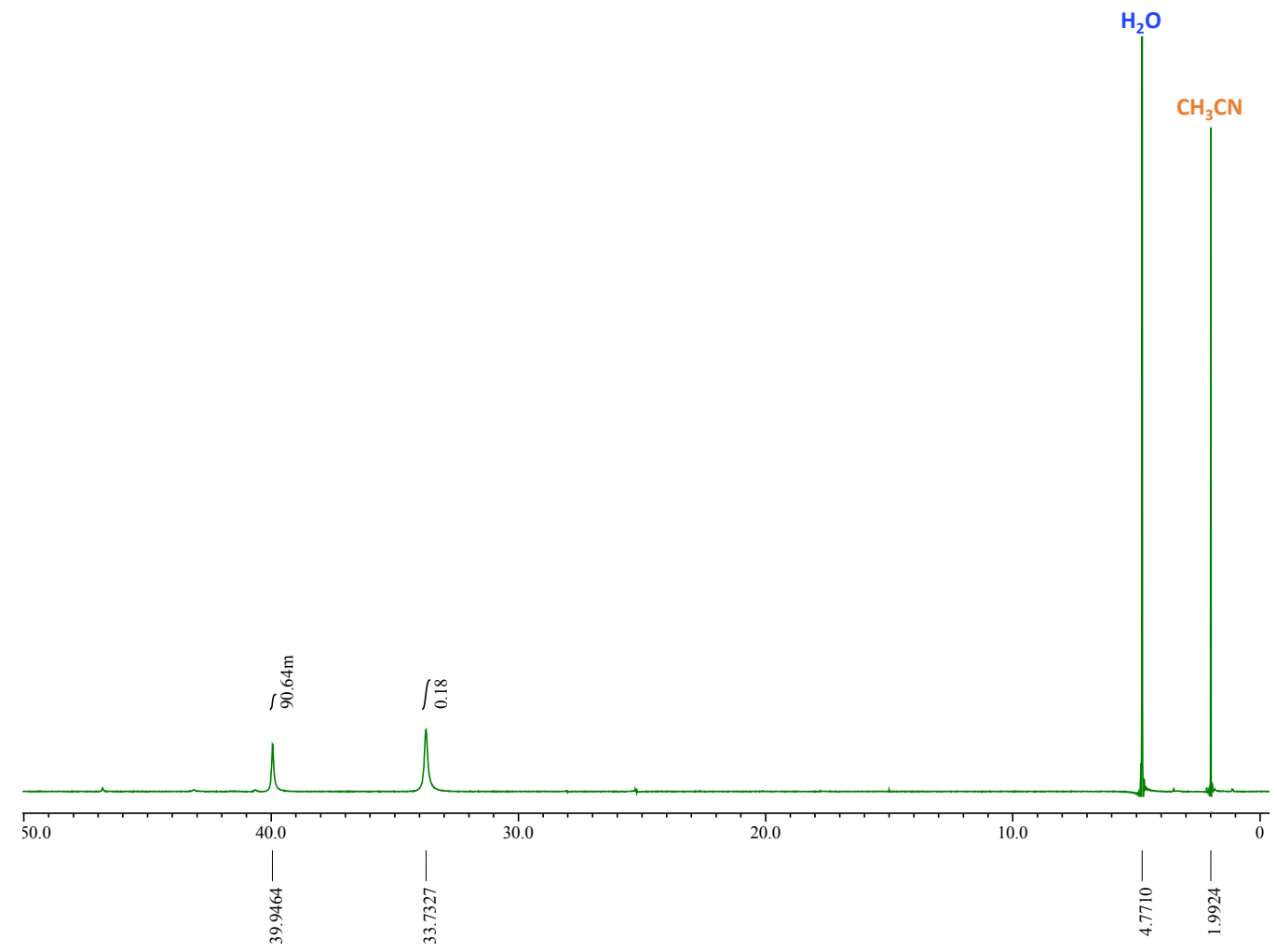

Figure S19. ${ }^{1} \mathrm{H}$ NMR spectrum $\left(400 \mathrm{MHz}, \mathrm{D}_{2} \mathrm{O}, 25^{\circ} \mathrm{C}\right)$ of $\mathrm{Cu}_{3}\left(\mu_{3}-\mathrm{OH}\right)(\mu-\mathrm{pz})_{3}\left(\mathrm{NO}_{3}\right)_{2}\left(\mathrm{CH}_{3} \mathrm{CN}\right)(\mathbf{1 b})$.

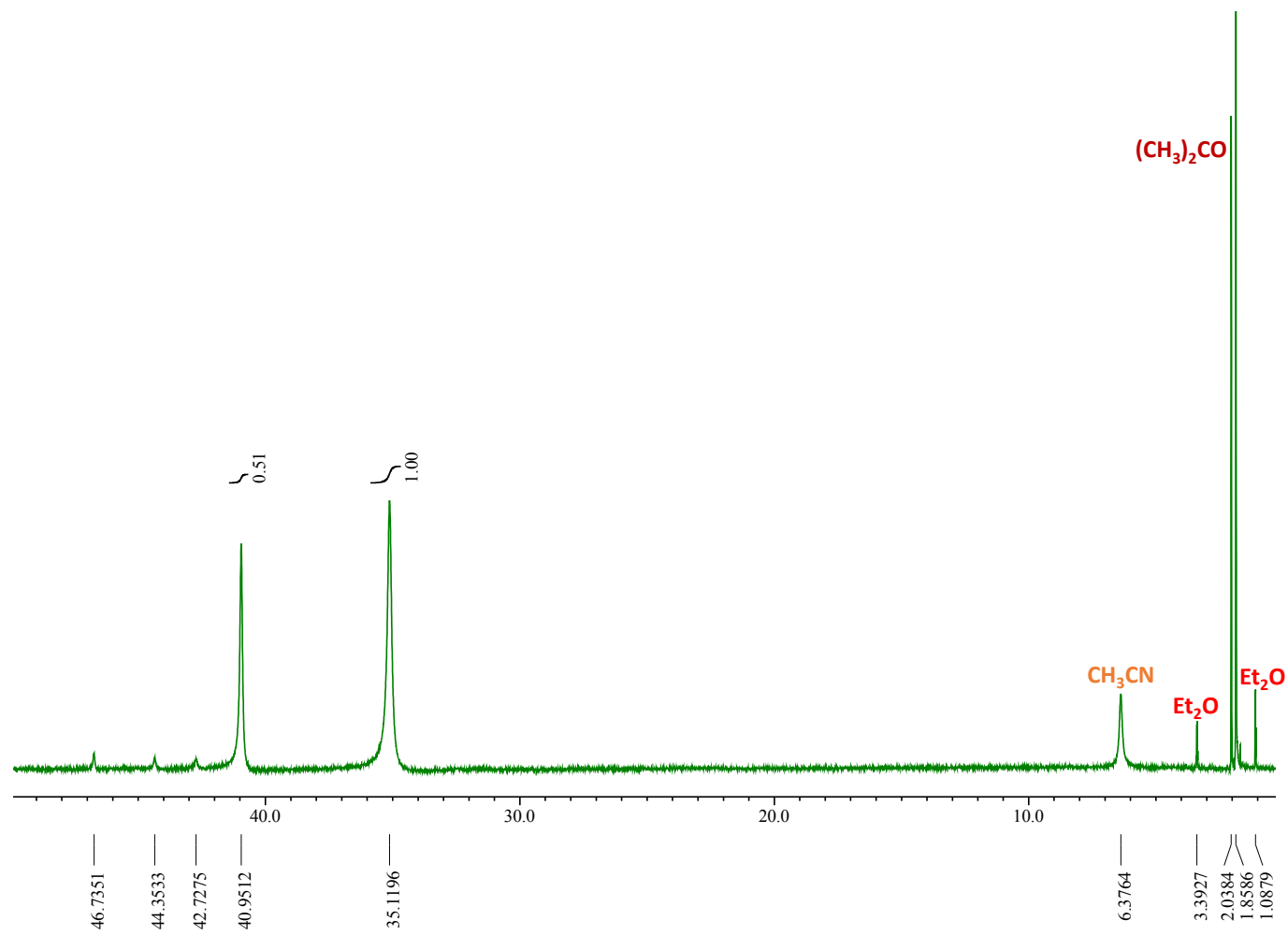

Figure S20. ${ }^{1} \mathrm{H}$ NMR spectrum $\left(400 \mathrm{MHz},\left(\mathrm{CD}_{3}\right)_{2} \mathrm{CO}, 25{ }^{\circ} \mathrm{C}\right)$ of $\mathrm{Cu}_{3}\left(\mu_{3}-\mathrm{OH}\right)(\mu-\mathrm{pz})_{3}\left(\mathrm{NO}_{3}\right)_{2}\left(\mathrm{CH}_{3} \mathrm{CN}\right)(\mathbf{1 b})$. 


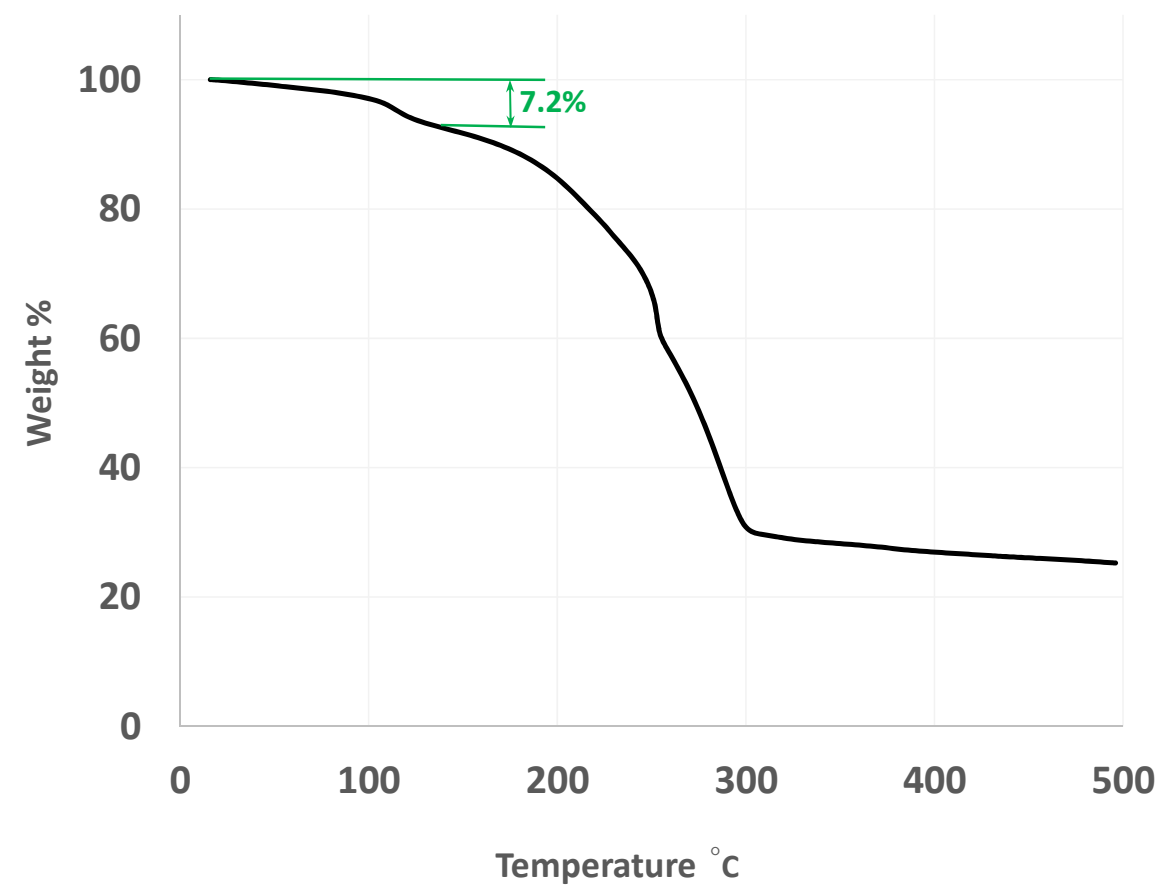

Figure S21. Thermogravimetric curve of $\mathrm{Cu}_{3}\left(\mu_{3}-\mathrm{OH}\right)(\mu-\mathrm{pz})_{3}\left(\mathrm{NO}_{3}\right)_{2}\left(\mathrm{CH}_{3} \mathrm{CN}\right)(\mathbf{1 b})$, heated at $5{ }^{\circ} \mathrm{C} / \mathrm{min}$ under $\mathrm{N}_{2}$. Calculated loss of the $\mathrm{CH}_{3} \mathrm{CN}$ molecule: $7.15 \%$; observed: $7.2 \%$.

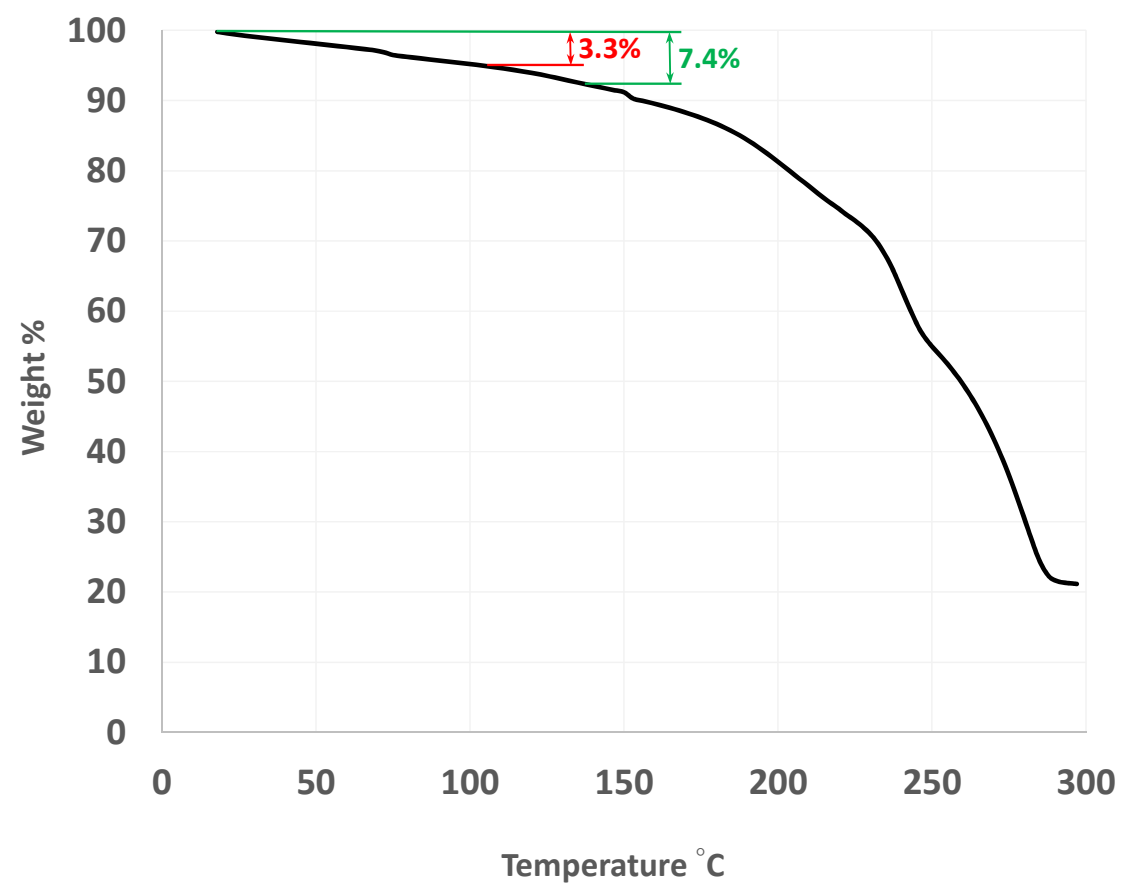

Figure S22. Thermogravimetric curve of $\mathrm{Cu}_{3}\left(\mu_{3}-\mathrm{OH}\right)(\mu-\mathrm{pz})_{3}\left(\mathrm{NO}_{3}\right)_{2}\left(\mathrm{H}_{2} \mathrm{O}\right)(\mathbf{1 a})$, heated at $5{ }^{\circ} \mathrm{C} / \mathrm{min}$ under $\mathrm{N}_{2}$. Calculated loss of the $\mathrm{H}_{2} \mathrm{O}$ molecule: $3.27 \%$; observed loss by the same temperature as in the case of $1 \mathbf{b}\left(135^{\circ} \mathrm{C}\right): 7.4 \%$. 


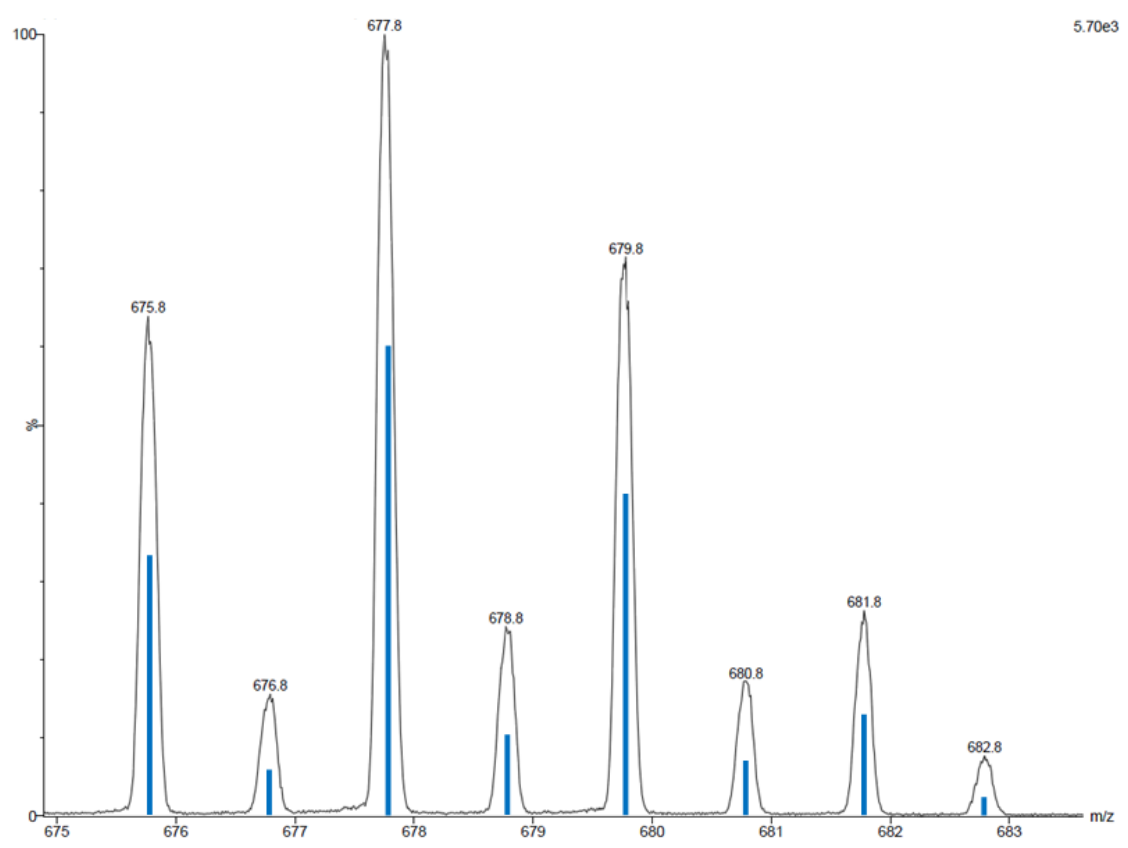

Figure S23. Predicted (blue lines) and observed isotopic pattern for $\left[\mathrm{Na}_{2} \mathrm{Cu}_{4} \mathrm{O}_{3}(\mathrm{pz})_{4}\left(\mathrm{NO}_{3}\right)\right]^{-}$.

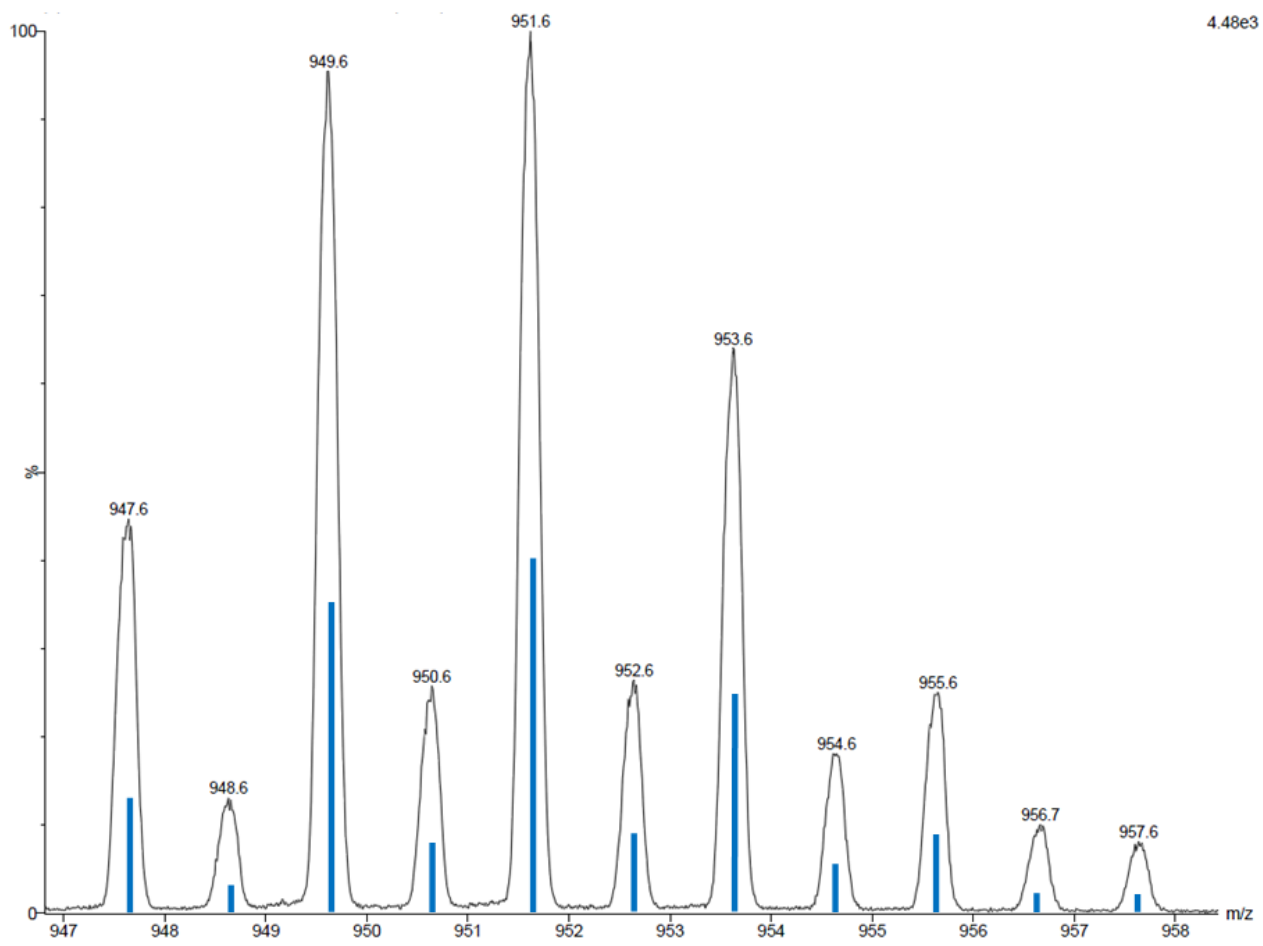

Figure S24. Predicted (blue lines) and observed isotopic pattern for $\left[\mathrm{Cu}_{6} \mathrm{O}_{2}(\mathrm{pz})_{5}\left(\mathrm{NO}_{3}\right)_{3}(\mathrm{OH})\right]^{-}$. 


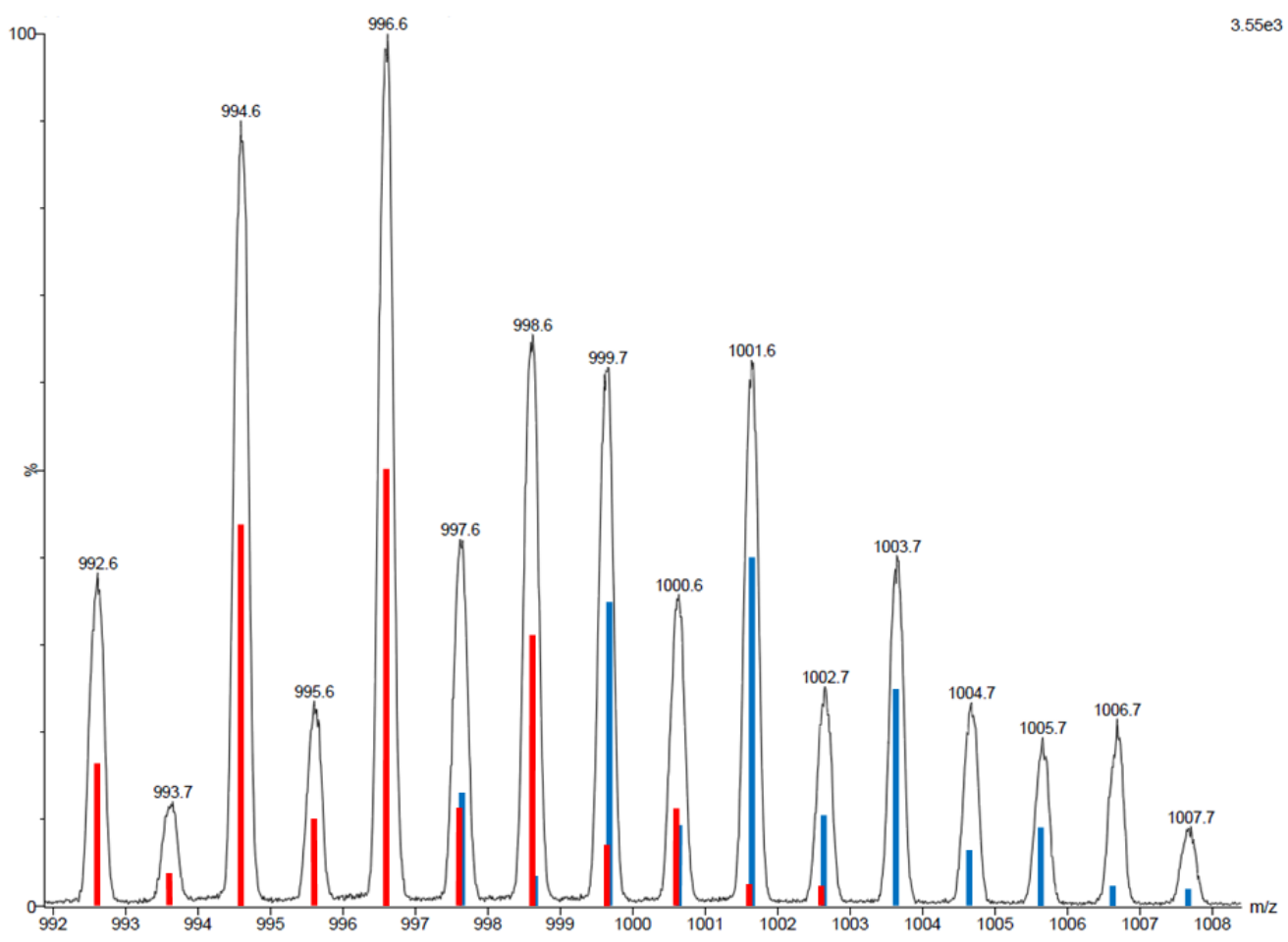

Figure S25. Predicted (red and blue lines, respectively) and observed isotopic patterns for partially overlapped $\left[\mathrm{Cu}_{6} \mathrm{O}_{2}(\mathrm{pz})_{5}\left(\mathrm{NO}_{3}\right)_{4}\right]^{-}$and $\left[\mathrm{Cu}_{6} \mathrm{O}_{2}(\mathrm{pz})_{6}\left(\mathrm{NO}_{3}\right)_{3}\right]^{-}$.

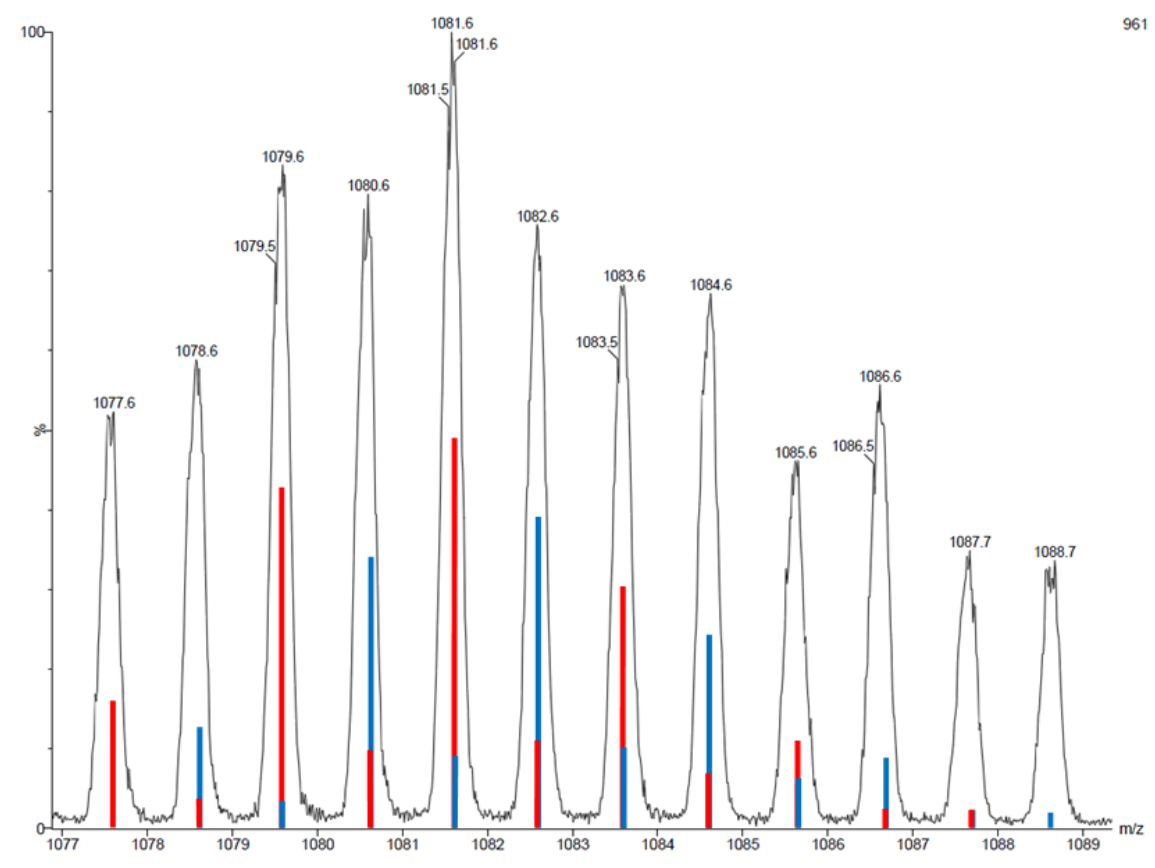

Figure S26. Predicted (red and blue lines, respectively) and observed isotopic patterns for almost completely overlapped $\left[\mathrm{Cu}_{6}(\mathrm{OH})_{3}(\mathrm{pz})_{6}\left(\mathrm{NO}_{3}\right)_{3}\left(\mathrm{HCO}_{3}\right)\right]^{-}$and $\left[\mathrm{Cu}_{6}(\mathrm{OH})_{3}(\mathrm{pz})_{6}\left(\mathrm{NO}_{3}\right)_{4}\right]^{-}$. 